\title{
Penerapan CBIS Untuk Mendukung Keputusan Manajemen dalam Menghitung Index Kinerja Karyawan PT Devrindo Wydia Karawang Menerapkan Preference Selection Index
}

\author{
Tubagus Ahmad Darojat \\ Universitas Singaperbangsa Karawang, Jawa Barat, Indonesia. \\ Email: bagus2m@gmail.com
}

\begin{abstract}
Abstrak-Pada penelitian ini penulis menerapkan suatu metode dalam computer base information system (CBIS) yaitu Preference Selection Index atau dikenal dengan metode PSI. Hal ini bertujuan untuk menghasilkan index preferensi dari tiaptiap karyawan, yang nantinya nilai index tersebut dijadikan sebagai ukuran terhadap suatu kinerja karyawan sehingga dikenal dengan Index Kinerja Karyawan. Alternatif data dari penelitian penulis gunakan sebanyak 30 data sebagai sample yang akan dihitung Index Kinerja Karyawan. Disamping data karyawan, penulis juga menggunakan beberapa kriteria dalam pengukuran Index Kinerja Karyawan, seperti kedisiplinan, loyalitas, masa kerja, sanksi dan teguran, pendidikan. Kriteria tersebut sangat mempengaruhi penilaian dari index kinerja karyawan. Diharapkan hasil dari pengukuran memberikan hasil keputusan yang tepat bagi karyawan dalam menghitung Index Kinerja Karyawan.
\end{abstract}

Kata Kunci: Index Kinerja Karyawan, Kinerja Karyawan, PSI, CBIS

Abstract-In this study the authors applied a method in the computer information base system (CBIS), the Preference Selection Index, or known as the PSI method. It aims to produce a preference index of each employee, which later the index value is used as a measure of employee performance so it is known as the Employee Performance Index. Alternative data from the study the author uses 30 data as samples to be calculated Employee Performance Index. In addition to employee data, the author also uses several criteria in measuring the Employee Performance Index, such as discipline, loyalty, years of service, sanctions and reprimands, education. These criteria greatly affect the assessment of employee performance index. It is expected that the results of the measurement provide the right decision for employees in calculating the Employee Performance Index.

Keywords: Employee Performance Index, Employee Performance, PSI, CBIS

\section{PENDAHULUAN}

Karyawan merupakan suatu asset yang paling berharga yang dimiliki perusahaan didalam kelangsungan hidup perusahaan. Tidak jarang perusahaan akan tumbuh besar apabila diiringi dengan kinerja yang terbaik dari para karyawannya. Salah satu masalah yang sering muncul bagi manajemen yaitu penentuan karyawan yang berkinerja baik. Sehingga sering ditemui keputusan yang tidak tepat di dalam pemberian reward kepada karyawan yang memiliki kinerja baik dibanding yang lainnya. Reward yang diberikan kepada karyawan memberikan manfaat yang sangat besar dalam prilaku kerja yang baik. Karyawan akan termotivasi untuk meningkatkan kinerja yang dihasilkannya dan hal ini akan memberikan kembali manfaat kepada perusahaan sebagai pemberi reward. Walaupun dalam pekerjaannya karyawan sudah terbantu dengan adanya sistem informasi, namun tetap perusahaan diharap bisa lebih memberikan motivasi yang lebih dalam bentuk reward kepada karyawan.

Adanya perkembangan dari perangkat lunak, khususnya Computer Base Information System (CBIS) memudahkan manajemen dalam melakukan analisa-analisa terhadap kebutuhan manajemen. Salah satu hal yang memberikan kemudahan yaitu dalam penilaiaan kinerja karyawan. Penerapan komputer menjadi suatu tolok ukur keberhasilan perusahaan dalam beraktifitas. Salah satunya peningkatan keputusan bagi manajemen dalam menyelesaikan masalah[1], [2]. Hal ini dapat menerapkan sistem pendukung keputusan. Hasil akhir dari sistem informasi ini memberikan keputusan yang tepat bagi manajemen dalam menyelesaikan permasalahan yang dihadapi[3].

Pada penelitian terdahulu, Mesran (2019) melakukan penelitian dalam peningkatan kinerja dosen[4], dalam penentuan lokasi pemasaran CBIS juga dapat digunakan untuk menghasilkan keputusan yang tepat tentang lokasi pemasaran[5]. Banyak lagi penelitian yang berhubungan dengan keputusan manajemen, seperti penerapan teknologi informasi dalam menghasilkan keputusan yang efektif [6].

Dari penjelasan di atas, penulis tertarik untuk melakukan analisa pengukuran IKK terhadap karyawa pada perusahaan XYZ. Hasil dari penelitian diharapkan dapat memberikan kontribusi pengembangan ilmu pengetahuan, dengan menerapkan CBIS dan bidang ekonomi mampu menghasilkan suatu keputusan yang dapat memberikan kemudahan dalam pengambilan suatu keputusan, khususnya terhadap kinerja karyawan.

\section{METODE PENELITIAN}

\subsection{Computer Base Information System (CBIS)}

Hingga saat ini perkembangan perangkat lunak bahkan lebih cepat dibandingkan dengan perkembangan komputer itu sendiri. Hal ini menunjukkan bahwa perangkat lunak begitu dibutuhkan oleh baik perorangan, instansi, maupun perusahaan didalam pengembangan organisasi. Kebutuhan perangkat lunak, salah satunya sistem informasi begitu 
diperlukan bagi perusahaan dalam memaksimalkan proses pekerjaan yang berlangsung. Salah satu bidang dalam sistem informasi yang memberikan kemudahan bagi manajemen yaitu dalam memberikan dukungan terhadap keputusan manajemen, yang dikenal dengan sistem pendukung keputusan[7]. Sistem Pendukung Keputusan merupakan sistem informasi yang diterapkan pada komputer yang memberikan penyelesaian masalah bagi manajer[3], [8], [9]. Banyak penelitian yang menerapkan sistem pendukung keputusan, sebagai contoh peningkatan efektifitas dalam penilaian kinerja karyawan untuk peningkatan motivasi kerja[10], menentukan lokasi pemasaran yang tepat[11].

\subsection{Index Kinerja Karyawan (IKK)}

Index Kinerja Karyawan atau dikenal dengan IKK, merupakan salah satu hasil yang di berikan oleh sistem perhitungan berbasis kinerja terhadap karyawan pada suatu perusahaan. Index Kinerja Karyawan merupakan suatu rentang nilai yang memberikan pengukuran terhadap nilai dari suatu kinerja karyawan berdasarkan kriteria-kriteria yang diberikan saat perhitungan IKK tersebut[10].

Pada penelitian ini digunakan metode Preference Selection Index (PSI) yang dapat menghasilkan Index Preferensi terhadap nilai IKK dari karyawan yang dinilai, sesuai dengan kriteria-kriteria yang dibutuhkan. Kriteria yang digunakan dalam penilaian IKK, merupakan kriteria yang digunakan bagi manajemen dalam penentukan ukuran kinerja karyawan. Index Karyawan yang melewati target yang ditentukan maka akan memiliki nilai tertinggi, sehingga dari nilai Index yang dihasilkan dari perhitungan, maka akan menghasilkan suatu nilai Index Kinerja Karyawan (IKK).

\subsection{Preference Selection Index.}

Metode preference selection index merupakan metode yang banyak digunakan dan berkembang dibidang pengukuran terhadap suatu index preferensi, baik di bidang ekonomi, komputer maupun di bidang lain, seperti teknik[5], [12], [13]. Terdapat beberapa langkah didalam menghasilkan index preferensi dari PSI[14]-[16]. Hasil akhir berupa nilai index preferensi yang bisa menentukan peringkat dari sejumlah alternatif yang di sertakan dalam perhitungan index preferensi, berdasarkan kriteria yang digunakan[17].

\subsection{Metode Penelitian}

Pada penelitian ini penulis menerapkan beberapa metode didalam melakukan suatu penelitian. Penelitian ini merupakan jenis penelitian kuantitatif dengan membutuhkan sampel data yang diambil pada perusahaan Devrindo Wydia Karawang. Beberapa tahapan yang dilakukan yaitu:
a. Tahapan Pengumpulan Data
b. Tahapan Studi Literatur Terhadap Penelitian Terkait
c. Tahapan Analisis Data
d. Tahapan Implementasi Computer Base Information System
e. Tahapan Pengambilan Kesimpulan

\section{HASIL DAN PEMBAHASAN}

Beberapa data yang penulis ambil dari PT. Devrindo Wydia Karawang, diantaranya yaitu data karyawan, data kriteria yang mempengaruhi dalam perhitungan Index Kinerja Karyawan (IKK). Sebanyak 15 data contoh yang diambil. Data ini nantinya akan dikenal dengan sebagai data alternatif dalam perhitungan terhadap Index Kinerja Karyawan (IKK). Berikut Data karyawan yang penulis kumpulan pada perusahaan, yang terlihat pada tabel 1.

Tabel 1. Data Karyawan.

\begin{tabular}{cc}
\hline Id Karyawan & Nama Karyawan \\
\hline K01 & Karyawan 1 \\
K02 & Karyawan 2 \\
K03 & Karyawan 3 \\
K04 & Karyawan 4 \\
K05 & Karyawan 5 \\
K06 & Karyawan 6 \\
K07 & Karyawan 7 \\
K08 & Karyawan 8 \\
K09 & Karyawan 9 \\
K010 & Karyawan 10 \\
K011 & Karyawan 11 \\
K012 & Karyawan 12 \\
K013 & Karyawan 13 \\
K014 & Karyawan 14 \\
K015 & Karyawan 15 \\
\hline
\end{tabular}


JURNAL MEDIA INFORMATIKA BUDIDARMA

Volume 4, Nomor 1, Januari 2020, Page 167-171

ISSN 2614-5278 (media cetak), ISSN 2548-8368 (media online)

Available Online at https://ejurnal.stmik-budidarma.ac.id/index.php/mib

DOI 10.30865/mib.v4i1.1933

Berikut data kriteria ataupun syarat yang digunakan dalam perhitungan Index Kinerja Karyawan, dapat dilihat pada tabel 2 .

Tabel 2. Kriteria yang digunakan.

\begin{tabular}{ccc}
\hline Kriteria & Nama Kriteria & Jenis \\
\hline C1 & Disiplin Kerja & Benefit \\
\hline C2 & Loyalitas & Benefit \\
C3 & Masa Kerja dan Pengalaman & Benefit \\
C4 & Sanksi dan Teguran & Cost \\
C5 & Pendidikan & Benefit \\
\hline
\end{tabular}

Pada pengumpulan data di perusahaan Devrindo Wydia Karawang, penulis mengambil data sample yang saling berhubungan dengan data syarat/kriteria yang harus dipenuhi. Terlihat data-data yang penulis diambil pada tabel 3, data ini dikenal dengan data kecocokan antara karyawan dengan kriteria.

Tabel 3. Data kecocokan Karyawan dan Kriteria

\begin{tabular}{|c|c|c|c|c|c|c|}
\hline $\begin{array}{c}\text { Id } \\
\text { Karyawan }\end{array}$ & Nama Karyawan & $\begin{array}{c}\text { Disiplin } \\
\text { Kerja }\end{array}$ & Loyalitas & $\begin{array}{c}\text { Masa Kerja dan } \\
\text { Pengalaman }\end{array}$ & $\begin{array}{c}\text { Sanksi dan } \\
\text { Teguran }\end{array}$ & Pendidikan \\
\hline K01 & Karyawan 1 & Sangat Baik & Baik & 4 tahun & $1 \mathrm{x}$ & S1 \\
\hline K02 & Karyawan 2 & Baik & Sangat Baik & 1 tahun & $3 x$ & S1 \\
\hline K03 & Karyawan 3 & Baik & Baik & 3 tahun & $1 \mathrm{x}$ & S1 \\
\hline K04 & Karyawan 4 & Sangat Baik & Sangat Baik & 4 tahun & $1 \mathrm{x}$ & D3 \\
\hline K05 & Karyawan 5 & Baik & Baik & 6 tahun & $1 \mathrm{x}$ & $\mathrm{S} 1$ \\
\hline K06 & Karyawan 6 & Baik & Sangat Baik & 3.5 tahun & $1 \mathrm{x}$ & SMA \\
\hline K07 & Karyawan 7 & Baik & Baik & 2.5 tahun & $1 \mathrm{x}$ & $\mathrm{S} 1$ \\
\hline K08 & Karyawan 8 & Sangat Baik & Baik & 2 tahun & $2 x$ & SMA \\
\hline K09 & Karyawan 9 & Baik & Sangat Baik & 3 tahun & $3 x$ & SMA \\
\hline K010 & Karyawan 10 & Cukup Baik & Baik & 5 tahun & $2 x$ & S1 \\
\hline K011 & Karyawan 11 & Baik & Baik & 4 tahun & $1 \mathrm{x}$ & $\mathrm{S} 1$ \\
\hline K012 & Karyawan 12 & Sangat Baik & Sangat Baik & 6 tahun & $2 x$ & D3 \\
\hline K013 & Karyawan 13 & Baik & Baik & 4.5 tahun & $1 \mathrm{x}$ & S1 \\
\hline K014 & Karyawan 14 & Sangat Baik & Baik & 1 tahun & $1 \mathrm{x}$ & S1 \\
\hline K015 & Karyawan 15 & Cukup Baik & Baik & 3 tahun & $1 \mathrm{x}$ & D3 \\
\hline
\end{tabular}

Pada Computer Base Information System pada dasarnya data diatas sebelum diolah terlebih dahulu harus di kelompokkan dalam satu nilai, hal ini bertujuan agar komputer mudah dalam melakukan penilaian, seperti data Sangat Baik dikelompokkan dengan nilai 5, Baik dikelompokkan dengan nilai 4 begitu seterusnya. Untuk data pendidikan S1 dikelompokkan dengan nilai 4, begitu selanjutnya. Sehingga data pengelompokkan terlihat pada tabel 4 dan tabel 5.

Tabel 4. Pengelompokkan Disiplin Kerja dan Loyalitas

\begin{tabular}{cc}
\hline Keterangan & Bobot \\
\hline Sangat Baik & 5 \\
Baik & 4 \\
Cukup & 3 \\
Kurang & 2 \\
Tidak Baik & 1 \\
\hline
\end{tabular}

Tabel 5. Pengelompokkan Pendidikan

\begin{tabular}{cc}
\hline Keterangan & Bobot \\
\hline S2 & 5 \\
S1 & 4 \\
D3 & 3 \\
D1 & 2 \\
SMA & 1 \\
\hline
\end{tabular}

Untuk data masa kerja dan pengalaman serta sanksi dan teguran, tidak dilakukan pengelompokkan, hal ini dikarenakan pada data tersebut terkandung nilai yang bisa langsung diproses. Hasil pengelompokkan terhadap data-data pada tabel 3 dapat dilihat di bawah ini. 
Tabel 6. Data Hasil Pengelompokan

\begin{tabular}{ccccccc}
\hline $\begin{array}{c}\text { Id } \\
\text { Karyawan }\end{array}$ & Nama Karyawan & $\begin{array}{c}\text { Disiplin } \\
\text { Kerja }\end{array}$ & Loyalitas & $\begin{array}{c}\text { Masa Kerja } \\
\text { dan } \\
\text { Pengalaman }\end{array}$ & $\begin{array}{c}\text { Sanksi } \\
\text { dan } \\
\text { Teguran }\end{array}$ & Pendidikan \\
\hline K01 & Karyawan 1 & 5 & 4 & 4 & 1 & 4 \\
K02 & Karyawan 2 & 4 & 5 & 1 & 3 & 4 \\
K03 & Karyawan 3 & 4 & 4 & 3 & 1 & 4 \\
K04 & Karyawan 4 & 5 & 5 & 4 & 1 & 3 \\
K05 & Karyawan 5 & 4 & 4 & 6 & 1 & 4 \\
K06 & Karyawan 6 & 4 & 5 & 3.5 & 1 & 1 \\
K07 & Karyawan 7 & 4 & 4 & 2.5 & 1 & 1 \\
K08 & Karyawan 8 & 5 & 4 & 2 & 2 & 4 \\
K09 & Karyawan 9 & 4 & 5 & 3 & 2 & 4 \\
K010 & Karyawan 10 & 3 & 4 & 5 & 1 & 4 \\
K011 & Karyawan 1 & 4 & 4 & 4 & 1 & 4 \\
K012 & Karyawan 12 & 5 & 5 & 6 & 1 & 4 \\
K013 & Karyawan 13 & 4 & 4 & 4.5 & 1 & 3 \\
K014 & Karyawan 14 & 5 & 4 & 1 & 3 & 4 \\
K015 & Karyawan 15 & 3 & 4 & 3 & 1 & 4 \\
\hline
\end{tabular}

Dengan penerapan CBIS, khususnya dengan menerapkan metode Preference Selection Index diperoleh nilai Index Kinerja Karyawan (IKK) sebagai berikut:

Tabel 7. Nilai Index Kinerja Karyawan (IKK)

\begin{tabular}{ccc}
\hline Id Karyawan & Nama Karyawan & $\begin{array}{c}\text { Nilai } \\
\text { IKK }\end{array}$ \\
\hline K01 & Karyawan 1 & 0.91529 \\
K02 & Karyawan 2 & 0.71988 \\
K03 & Karyawan 3 & 0.85180 \\
K04 & Karyawan 4 & 0.91080 \\
K05 & Karyawan 5 & 0.90694 \\
K06 & Karyawan 6 & 0.75161 \\
K07 & Karyawan 7 & 0.84261 \\
K08 & Karyawan 8 & 0.61389 \\
K09 & Karyawan 9 & 0.59932 \\
K010 & Karyawan 10 & 0.73612 \\
K011 & Karyawan 11 & 0.87018 \\
K012 & Karyawan 12 & 0.84023 \\
K013 & Karyawan 13 & 0.87937 \\
K014 & Karyawan 14 & 0.86015 \\
K015 & Karyawan 15 & 0.75424 \\
\hline
\end{tabular}

Dari perhitungan diperoleh nilai range terhadap Index Kinerja Karyawan yaitu dari 0-1, dan manajemen dapat menetapkan seperti range nilai 0-0.50 merupakan karyawan dengan kinerja Kurang Baik, nilai range 0.51-0.75 merupakan karyawan dengan kinerja Cukup, range 0.76-0.85 merupakan karyawan dengan kinerja Baik, dan range 0.86-1 merupakan karyawan dengan kinerja Sangat Baik, sehingga hasil dari penilaian kinerja karyawan tersebut dapat dilihat sebagai berikut:

Tabel 8. Nilai Index Kinerja Karyawan (IKK)

\begin{tabular}{clcc}
\hline Id Karyawan & Nama Karyawan & $\begin{array}{c}\text { Nilai } \\
\text { IKK }\end{array}$ & Keterangan \\
\hline K01 & Karyawan 1 & 0.91529 & Sangat Baik \\
K02 & Karyawan 2 & 0.71988 & Cukup \\
K03 & Karyawan 3 & 0.85180 & Cukup \\
K04 & Karyawan 4 & 0.91080 & Baik \\
K05 & Karyawan 5 & 0.90694 & Cukup \\
K06 & Karyawan 6 & 0.75161 & Sangat Baik \\
K07 & Karyawan 7 & 0.84261 & Sangat Baik \\
K08 & Karyawan 8 & 0.61389 & Baik \\
K09 & Karyawan 9 & 0.59932 & Cukup \\
K010 & Karyawan 10 & 0.73612 & Cukup \\
K011 & Karyawan 11 & 0.87018 & Sangat Baik \\
\hline
\end{tabular}


Available Online at https://ejurnal.stmik-budidarma.ac.id/index.php/mib DOI 10.30865/mib.v4i1.1933

\begin{tabular}{lllc}
\hline K012 & Karyawan 12 & 0.84023 & Sangat Baik \\
K013 & Karyawan 13 & 0.87937 & Baik \\
K014 & Karyawan 14 & 0.86015 & Sangat Baik \\
K015 & Karyawan 15 & 0.75424 & Cukup \\
\hline
\end{tabular}

Dari penerapan CBIS, dengan menerapkan metode Preference Selection Index dapat terlihat bahwa keputusan yang dapat diambil oleh manajemen terhadap karyawan yang memiliki kinerja Sangat Baik dapat diberikan reward ataupun bonus.

\section{KESIMPULAN}

Dari penelitian dapat disimpulkan, hasil yang diberikan dalam penerapan Preference Selection Index (PSI) yaitu berupa Index Preferensi, dapat digunakan sebagai Index Kinerja Karyawan (IKK). IKK yang dihasilkan sangat tepat, karna bersifat objektif yang dihasilkan dari CBIS, dan dapat dilakukan perangkingan dengan mudah, sehingga diperoleh karyawan-karyawan yang memiliki kinerja sangat baik, baik, dan kurang baik. Hasil Index Kinerja Karyawan (IKK) dapat digunakan bagi manajemen dalam pemberian reward/bonus kepada karyawan yang memiliki kinerja sangat baik.

\section{REFERENCES}

[1] J. Hutahaean, Konsep Sistem Informasi. Deepublish, 2018.

[2] J. Simarmata, Pengenalan Teknologi Komputer dan Informasi. Yogyakarta: Andi, 2006.

[3] Kusrini, Konsep dan Aplikasi Sistem Pendukung Keputusan. 2007.

[4] M. Mesran, T. M. Diansyah, and F. Fadlina, "Implemententasi Metode Rank Order Cendroid (ROC) dan Operational Competitiveness Rating Analysis (OCRA) dalam Penilaian Kinerja Dosen Komputer Menerapkan (Studi Kasus: STMIK Budi Darma)," Pros. Semin. Nas. Ris. Inf. Sci., vol. 1, no. 0, pp. 822-834, Sep. 2019.

[5] S. H. Sahir et al., "The Preference Selection Index method in determining the location of used laptop marketing," Int. J. Eng. Technol., vol. 7, no. 3.4 Special Issue 4, 2018.

[6] E. Purba, "Peranan Teknologi Informasi Dalam Mengefektifkan Keputusan Pemberian Dana Corporate Social Responsibilty ( CSR )," Media Inform. Budidarma, vol. 2, no. 3, pp. 69-75, 2018.

[7] D. Nofriansyah, Konsep Data Mining Vs Sistem Pendukung Keputusan. 2015.

[8] S. Kusumadewi, S. Hartati, A. Harjoko, and R. Wardoyo, Fuzzy Multi-Attribute Decision Making (Fuzzy MADM). Yogyakarta: Graha Ilmu, 2006.

[9] D. Nofriansyah and S. Defit, Multi Criteria Decision Making (MCDM) pada Sistem Pendukung Keputusan. 2018.

[10] Mesran, J. Afriany, and S. H. Sahir, "Efektifitas Penilaian Kinerja Karyawan Dalam Peningkatan Motivasi Kerja Menerapkan Metode Rank Order Centroid (ROC) dan Additive Ratio Assessment (ARAS)," Semin. Nas. Ris. Inf. Sci., vol. 1, no. September, pp. 813-821, Sep. 2019.

[11] S. H. Sahir et al., "The Preference Selection Index Method in Determining the Location of Used Laptop Marketing," Int. J. Eng. Technol., vol. 7, pp. 260-263, 2018.

[12] M. K. Siahaan, M. Mesran, S. A. Hutabarat, and J. Afriany, "Sistem Pendukung Keputusan Penentuan Prioritas Pembangunan Daerah Menerapkan Metode Preference Selection Index (PSI)," KOMIK (Konferensi Nas. Teknol. Inf. dan Komputer), vol. 2, no. 1, pp. 370-375, 2018.

[13] Mesran, K. Tampubolon, R. D. Sianturi, F. T. Waruwu, and A. P. U. Siahaan, "Determination of Education Scholarship Recipients Using Preference Selection Index,” Int. J. Sci. Res. Sci. Technol., vol. 3, no. 6, pp. 230-234, 2017.

[14] M. Madić, J. Antucheviciene, M. Radovanović, and D. Petković, "Determination of laser cutting process conditions using the preference selection index method," Opt. Laser Technol., vol. 89, no. October 2016, pp. 214-220, 2017.

[15] F. Syahputra, M. Mesran, I. Lubis, and A. P. Windarto, "Sistem Pendukung Keputusan Pemilihan Guru Berprestasi Kota Medan Menerapkan Metode Preferences Selection Index (Studi Kasus: Dinas Pendidikan Kota Medan)," KOMIK (Konferensi Nas. Teknol. Inf. dan Komputer), vol. 2, no. 1, pp. 147-155, 2018.

[16] R. Khorshidi and A. Hassani, "Comparative analysis between TOPSIS and PSI methods of materials selection to achieve a desirable combination of strength and workability in A1/SiC composite," Mater. Des., vol. 52, no. June, pp. 999-1010, 2013.

[17] B. Vahdani, S. M. Mousavi, and S. Ebrahimnejad, "Soft computing-based preference selection index method for human resource management,” J. Intell. Fuzzy Syst., vol. 26, no. 1, pp. 393-403, 2014. 